\title{
Bioaccumulation of polonium $\left({ }^{210} \mathrm{Po}\right)$, uranium $\left({ }^{234} \mathrm{U},{ }^{238} \mathrm{U}\right)$ isotopes and trace metals in mosses from Sobieszewo Island, northern Poland
}

\author{
A. Boryło $^{1}$, W. Nowicki ${ }^{1}$, G. Olszewski $^{1}$, and B. Skwarzec ${ }^{1}$ \\ ${ }^{1}$ University of Gdańsk, Faculty of Chemistry, Sobieskiego 18, Gdańsk, POLAND, aborylo@chem.univ.gda.pl
}

\begin{abstract}
The objective of this study was determination of the polonium $\left({ }^{210} \mathrm{Po}\right)$, uranium $\left({ }^{234} \mathrm{U}\right.$ and $\left.{ }^{238} \mathrm{U}\right)$ radionuclides and trace metals $(\mathrm{Pb}, \mathrm{Fe}, \mathrm{Zn}, \mathrm{Cu}, \mathrm{Ni}, \mathrm{Cd}, \mathrm{Hg})$ concentrations in mosses samples from Sobieszewo Island near the phosphogypsum waste dump in Wiślinka (northern Poland). The obtained results revealed that the concentrations of ${ }^{210} \mathrm{Po},{ }^{234} \mathrm{U}$, and ${ }^{238} \mathrm{U}$ in the two analyzed kinds of mosses: Pleurozium schreberi and Dicranum scoparium were similar. Among the analyzed trace metals the highest concentration in mosses was recorded for iron, while the lowest for nickel, cadmium and mercury. The obtained studies showed that the sources of polonium and uranium isotopes, as well as trace metals in analyzed mosses are air city contaminations transported from Gdańsk and from existing in the vicinity the phosphogypsum waste heap in Wiślinka (near Gdańsk).
\end{abstract}

Key words: polonium, ${ }^{210} \mathrm{Po}$, uranium, ${ }^{234} \mathrm{U},{ }^{238} \mathrm{U}$, trace metals, mosses, Sobieszewo Island, northern Poland

\section{Introduction}

Sobieszewo Island is located between Gdańsk Bay and the delta of the Vistula river (northern Poland) and is the part of area of the city of Gdańsk (the southern Baltic Sea). Mosses are useful as bioindicators of environmental contamination for a variety of natural and artificial origin radionuclides, as well as trace metals (Delfanti et al., 1999). Trace metals may be defined as metals occuring at $1000 \mu \mathrm{g} \mathrm{g}^{-1}$ or less in the earth' $\mathrm{s}$ crust and may be classified as heavy or light with respect to density. Trace heavy metals have densities greater than $5 \mathrm{~g} \mathrm{~cm}^{-3}$ whereas light metals less than $5 \mathrm{~g} \mathrm{~cm}^{-3}$ (Osuji and Onjuke, 2004). Trace metals in the environment are a result of natural geochemical processes, as well as from the numerous anthropogenic sources and depending on dispersion according to wind direction, soil characteristics, and on the meteorological and climatic conditions of the site (Rosamilia et al., 2004). Uranium occurs naturally in the Earth's crust and is present in much higher concentrations (Skwarzec, 1995). The principal sources of uranium in natural environment are the wet and dry atmospheric and terrigenic fallout, as well as human activities particularly in agriculture (Skwarzec et al., 2002). Also higher uranium and polonium concentration were observed in the immediate vicinity of the area around the phosphogypsum waste dump (Boryło et al., 2009, 2012; Boryło and Skwarzec, 2011; Skwarzec et al., 2010). Polonium ${ }^{210}$ Po belongs to a natural uranium decay series starting from ${ }^{238} \mathrm{U}$ but its fate depends on further members of this series, e.g. ${ }^{226} \mathrm{Ra}$ and most of all on ${ }^{210} \mathrm{~Pb}$. Radon ${ }^{222} \mathrm{Rn}$ escaping from the Earth's surface constitutes the source of atmospheric ${ }^{210} \mathrm{Po}$ (Skwarzec, 1995). The main source of ${ }^{210} \mathrm{Po}$ in environment is ${ }^{210} \mathrm{~Pb}$ and ${ }^{210} \mathrm{Po}$ falling to the ground from atmosphere, but small amount of ${ }^{210} \mathrm{Po}$ is formed in situ as a result of the radioactive decay of uranium contained in seawater, a result of forest fires and volcanic eruptions (Skwarzec, 1995).

\section{Materials and Methods}

The samples of mosses (Dicranum scoparium and Pleurozium schreberi) were collected with five positions of Sobieszewo Island (northern Poland) (Fig. 1). Radionuclide analysis was performed only in the spring 2009 because the amount of research material collected in the autumn this year was relatively small. The concentrations of trace metals $(\mathrm{Fe}, \mathrm{Pb}, \mathrm{Ni}, \mathrm{Zn}, \mathrm{Cu}$ and Cd) were determined by two methods: AAS (atomic absorption spectrometry) and OES-ICP (atomic emission spectrometry with inductively coupled plasma). 


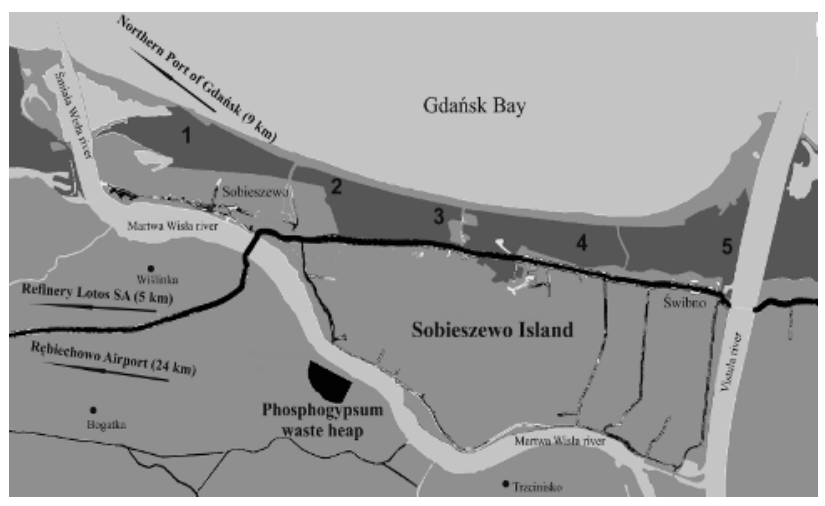

Fig. 1. The places of mosses samples collected.

The detection limit for all analyzed trace metals was $0.005 \mathrm{mg} \mathrm{l}^{-1}$. Mercury content was measured by cold vapor technique CV AAS (Nippon Instruments Corporation), the advantage of which is the high precision and accuracy of determination of mercury directly from the sample. The detection limit for mercury analysis was $0.002 \mathrm{ng} \mathrm{mg}^{-1}$. After chemical analysis in the rest of samples the polonium and uranium concentrations were determined by used alpha spectrometry (Skwarzec, 1995; 1997). The accuracy and precision of the radiochemical methods were within $10 \%$ based on an international laboratory comparison using International Atomic Energy Agency reference materials (IAEA-384, IAEA-385, IAEA-414). The results of ${ }^{210} \mathrm{Po},{ }^{234} \mathrm{U}$, and ${ }^{238} \mathrm{U}$ concentrations in analyzed samples are given with standard deviation (SD) calculated for a $95 \%$ confidence interval $( \pm 2 \sigma)$.

\section{Results and Discussion}

The obtained results of trace metals, polonium and uranium determination in mosses samples from Sobieszewo Island are given in Tables 1-3. The lead contents in analyzed mosses vary from $0.01 \mu \mathrm{g} \mathrm{g}^{-1} \mathrm{~d}$. wt. to $26.4 \mu \mathrm{g} \mathrm{g}^{-1} \mathrm{~d}$. wt. In the case of iron the highest concentrations were measured in samples of mosses collected in site 1 for Pleurozium schreberi and Dicranum scoparium (539.9 $\mu \mathrm{g} \mathrm{g}^{-1} \mathrm{~d}$. wt. and $255.9 \mu \mathrm{g} \mathrm{g}^{-}$ ${ }^{1} \mathrm{~d}$. wt. and $580.4 \mu \mathrm{g} \mathrm{g}^{-1} \mathrm{~d}$. wt. and $478.3 \mu \mathrm{g} \mathrm{g}^{-1} \mathrm{~d}$. wt. respectively). The values of zinc accumulation in analyzed mosses from Sobieszewo Island vary from 8.1 $\mu \mathrm{g} \mathrm{g}^{-1} \mathrm{~d}$. wt. to $66.4 \mu \mathrm{g} \mathrm{g}^{-1} \mathrm{~d}$. wt. The values of copper concentrations in analyzed mosses were between 6.7$28.3 \mu \mathrm{g} \mathrm{g}^{-1} \mathrm{~d}$. wt. Nickel concentrations in mosses range from $0.2 \mu \mathrm{g} \mathrm{g}^{-1}$ to $4.2 \mu \mathrm{g} \mathrm{g}^{-1} \mathrm{~d}$. wt. For all the analyzed mosses samples from Sobieszewo Island cadmium concentration was below the detection limit (b.d.1.), without of Dicranum scoparium samples taken in the autumn from site 2 (1.2 $\mu \mathrm{g} \mathrm{g}^{-1}$ d. wt.). Mercury concentrations in analyzed mosses species from Sobieszewo Island were between $0.04-0.08 \mu \mathrm{g} \mathrm{g}^{-1} \mathrm{~d}$. wt. The presence of heavy metals in Sobieszewo Island may be connected with industrial development in the area around this region. In the immediate vicinity of Sobieszewo Island (5 $\mathrm{km}$ of the island) in the southeastern part of Gdańsk the petroleum refinery Lotos SA, Gdańsk Power Station and "Remontowa" Shipyard SA are also located (Fig. 1). The higher levels of heavy metals were characterized for the spring season, which is connected with the fact that pollutants absorbed by mosses, covered in winter with a thick layer of snow do not have the ability to migrate into the environment.

The values of polonium and uranium concentrations in the two analyzed mosses samples were presented in Table 3. The values of the activity ratios ${ }^{234} \mathrm{U} /{ }^{238} \mathrm{U}$ in analyzed mosses ranged from $0.97 \pm 0.03$ to $1.00 \pm 0.07$ and indicate that uranium in analyzed species originates from the phosphogypsum waste heap in Wiślinka. In phosphoric rocks, which are used to production phosphoric acid, uranium is usually concentrated, in variable amounts. As a consequence, if dust particles, even very small ones, are captured by mosses, they can strongly increase the total uranium content of these organisms (Loppi et al., 2004). Any differences between the obtained concentrations of polonium and uranium measured for various sites of one species collection are connected with location and distance from potential sources of contamination. In the analyzed area the dominating winds were from western and southern directions (Fig. 2).

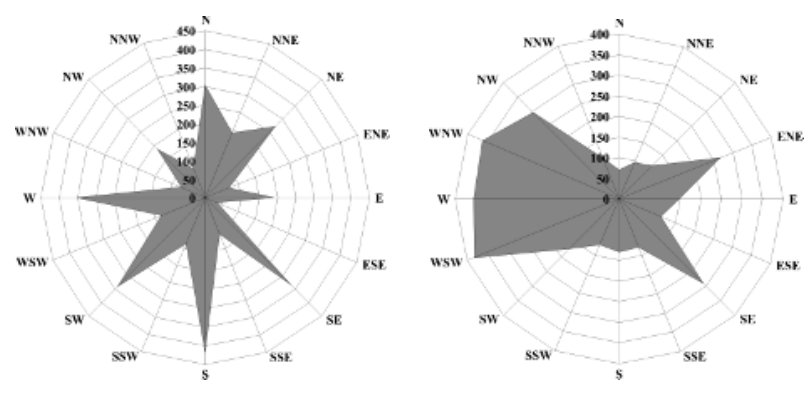

Fig. 2. Demonstrative wind roses for: Świbno (a), Rębiechowo Airport (b) (The winds and rains measurements data were obtained from Institute of Meteorology and Water Management, National Research Institute according to the agreement no WSP 190 G000 260111 between Institute of Meteorology and Water Management and University of Gdańsk).

The results of measurements from Rębiechowo Airport station (Fig. 2a) show that western winds are prevailing and blew in the direction of Sobieszewo Island through Gdańsk city, transporting pollution from this agglomeration. On the other hand the results from Świbno (Fig. 2b) station suggest that in this area southern winds are dominant and could transport phosphogypsum particles both with alpha emitters and trace metals directly to Sobieszewo Island. The values of trace metals, polonium and uranium concentrations in mosses from Sobieszewo Island were analyzed also by chemometric techniques: principal component analysis (PCA). On the 
a)

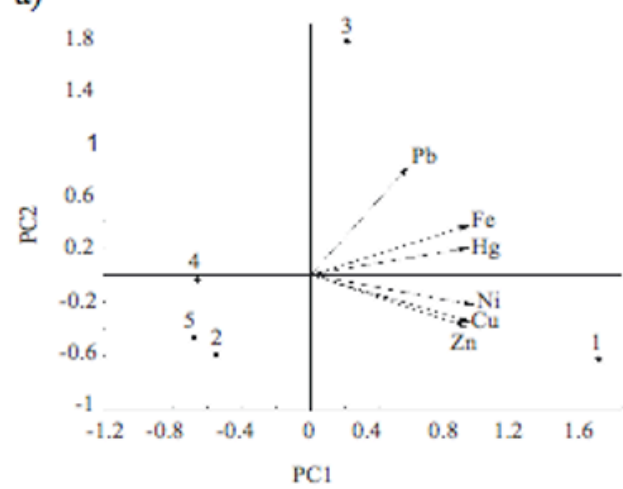

b)

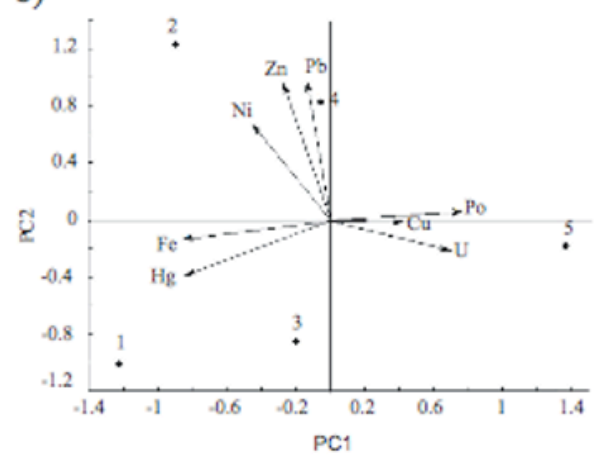

a)

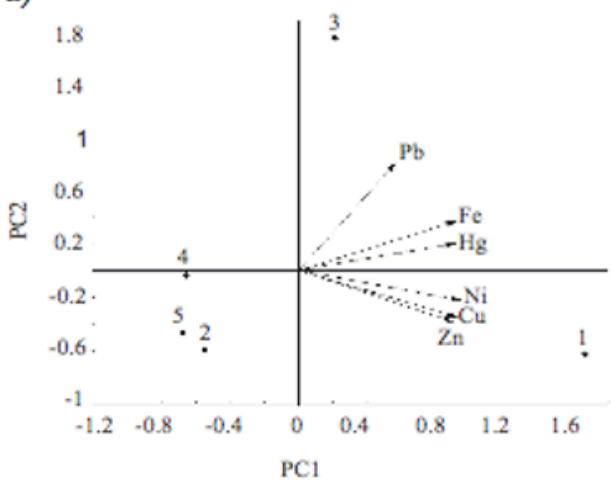

b)

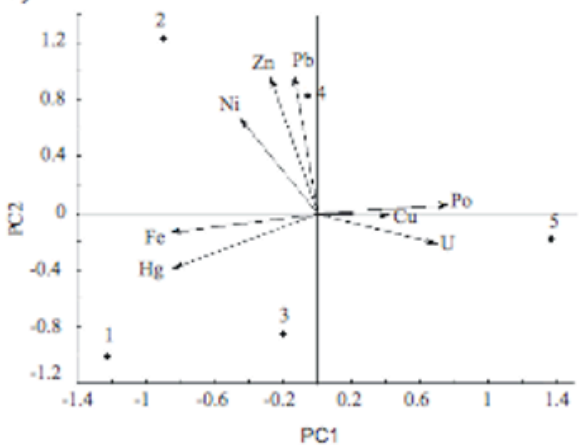

Fig. 3. Combined plots of PC1 vs. PC2 scores and loadings for Pleurozium schreberi collected in autumn (a) and spring (b).

basis of this technique we observed that sites 1 and 3 are more abundant in analyzed trace metals what can be explained by urban pollution transported by winds according to meteorological stations in Rębiechowo Airport. Probably trace metals are of the same origin (sites 1-4) but polonium and uranium is of phosphogypsum origin (site 5) (Fig. 3, 4).

\section{Conclusion}

The main aim of this study was determination of ${ }^{210} \mathrm{Po}$, ${ }^{234} \mathrm{U},{ }^{238} \mathrm{U}$ and trace metals $(\mathrm{Pb}, \mathrm{Fe}, \mathrm{Zn}, \mathrm{Cu}, \mathrm{Ni}, \mathrm{Cd}, \mathrm{Hg})$ concentrations in two kind of mosses from Sobieszewo Island (northern Poland). The value of the activity ratio ${ }^{234} \mathrm{U} /{ }^{238} \mathrm{U}$ of close to unity shows that the uranium in the analyzed samples is mainly natural, but there is a possible uranium contribution from fallout of dry and wet atmospheric. After resuspension of such particles dispersed in the air may be captured by mosses in accordance with prevailing wind directions. We also noticed that the concentrations of analyzed metals in mosses samples are higher in spring than in autumn and it can be explained by the fact that during winter mosses are covered with snow so migration of the absorbed elements is not possible.
Fig. 4. Combined plots of PC1 vs. PC2 scores and loadings for Dicranum scoparium collected in autumn (a) and spring (b).

\section{Acknowledgments}

The authors would like to thank the Ministry of Science and Higher Education for the financial support under grant DS/8120-4-0176-12.

\section{References}

1. Boryło A., Nowicki W., Skwarzec B., Isotopes of polonium ${ }^{210} \mathrm{Po}$, uranium ${ }^{234} \mathrm{U}$ and ${ }^{238} \mathrm{U}$ for industrialized areas in Poland (Wiślinka). J Environ Anal Chem 2009;89:677-685.

2. Boryło A, Skwarzec B. Bioaccumulation of polonium ${ }^{210} \mathrm{Po}$ and uranium $\left({ }^{234} \mathrm{U},{ }^{238} \mathrm{U}\right)$ in plants around phosphogypsum waste heap in Wislinka (northern Poland). Radiochim Acta 2011;99:1-13.

3. Boryło A., Skwarzec B., Olszewski G., The radiochemical contamination $\left({ }^{210} \mathrm{Po}\right.$ and $\left.{ }^{238} \mathrm{U}\right)$ of zone around phosphogypsum waste heap in Wiślinka. J of Environ Science and Health Part A 2012;47:675-687.

4. Delfanti R, Papucci C, Benco C. Mosses as indicators of radioactivity deposition around a coalfired power station. Sci Total Environ 1999;227:4956.

5. Loppi S., Di Lella A., Frati L., Protano G., Pirintsos S.A., Riccobono F., Lichens as biomonitors of 
depleted uranium in Kosovo. $\mathrm{J}$ of Atmosp Chem 2004;49:437-445

6. Osuji LC, Onjuke ChM. Trace heavy metals associated with crude oil: A case study of Ebocha-8 oil-spill-polluted site in Niger Delta, Nigeria. Chem Biodiv 2004;1:1708-1715.

7. Rosamilia S, Gaudino S, Sansone U, Belli M, Jeran Z, Ruisi S, Zucconi L. Uranium isotopes, metals and other elements in lichens and tree barks collected in Bosnia-Herzegovina. $\mathrm{J}$ of Atmosp Chem 2004;49:447-460.

8. Skwarzec B. Polon, uran i pluton w ekosystemie południowego Bałtyku. Rozprawy i monografie 6. Sopot: Instytut Oceanologii PAN;1995.
9. Skwarzec B. Radiochemical methods for the determination of polonium, radiolead, uranium and plutonium in environmental samples. Chem Anal 1997;42:107.

10. Skwarzec B, Boryło A, Strumińska DI. ${ }^{234} U$ and ${ }^{238} \mathrm{U}$ isotopes in water and sediments of the southern Baltic. J Environ Radioact 2002;61:345-363.

11. Skwarzec B, Boryło A, Kosińska A, Radzajewska S. Polonium $\left({ }^{210} \mathrm{Po}\right)$ and uranium $\left({ }^{234} \mathrm{U},{ }^{238} \mathrm{U}\right)$ in water, phosphogypsum and their bioaccumulation in plants around phosphogypsum waste heap in Wiślinka (northern Poland). Nukleonika 2010;2(55):187-195

Table 1. Average trace metals concentration in mosses samples collected in spring 2009 from Sobieszewo Island

\begin{tabular}{|c|c|c|c|c|c|c|c|c|}
\hline \multirow[b]{2}{*}{ Mosses species } & \multirow[b]{2}{*}{ Site } & $\mathrm{Pb}$ & $\mathrm{Fe}$ & $\mathrm{Zn}$ & $\mathrm{Cu}$ & $\mathrm{Ni}$ & $\mathrm{Cd}$ & $\mathrm{Hg}$ \\
\hline & & \multicolumn{7}{|c|}{$\left[\mu \mathrm{g} \mathrm{g}^{-1} \mathrm{~d} . \mathrm{wt}.\right]$} \\
\hline \multirow{5}{*}{ Pleurozium schreberi } & 1 & 0.01 & 539.9 & 15.4 & 14.0 & 1.0 & b.d.l. & 0.07 \\
\hline & 2 & 24.7 & 407.7 & 61.7 & 14.5 & 1.7 & b.d.l. & 0.07 \\
\hline & 3 & 5.7 & 260.4 & 26.4 & 6.7 & 0.2 & b.d.1. & 0.07 \\
\hline & 4 & 26.4 & 329.7 & 44.1 & 8.5 & 0.9 & b.d.1. & 0.06 \\
\hline & 5 & 10.4 & 319.1 & 30.0 & 28.3 & 1.0 & b.d.1. & 0.06 \\
\hline \multirow{5}{*}{ Dicranum scoparium } & 1 & 22.3 & 580.4 & 66.4 & 27.8 & 4.2 & b.d.1. & 0.08 \\
\hline & 2 & 9.1 & 426.5 & 53.9 & 18.4 & 1.7 & b.d.1. & 0.07 \\
\hline & 3 & 5.7 & 355.3 & 40.8 & 10.7 & 0.7 & b.d.1. & 0.08 \\
\hline & 4 & 19.2 & 285.6 & 27.8 & 11.6 & 0.2 & b.d.1. & 0.07 \\
\hline & 5 & 5.3 & 259.2 & 28.4 & 6.8 & 0.2 & b.d.l. & 0.06 \\
\hline
\end{tabular}

b.d.l. - below the detection limit

Table 2. Average trace metals concentration in mosses samples collected in autumn 2009 from Sobieszewo Island

\begin{tabular}{|c|c|c|c|c|c|c|c|c|}
\hline \multirow[b]{2}{*}{ Mosses species } & \multirow[b]{2}{*}{ Site } & $\mathrm{Pb}$ & $\mathrm{Fe}$ & $\mathrm{Zn}$ & $\mathrm{Cu}$ & $\mathrm{Ni}$ & $\mathrm{Cd}$ & $\mathrm{Hg}$ \\
\hline & & \multicolumn{7}{|c|}{$\left[\mu \mathrm{g} \mathrm{g}^{-1}\right.$ d. wt. $]$} \\
\hline \multirow{5}{*}{ Pleurozium schreberi } & 1 & 4.9 & 255.9 & 42.1 & 7.1 & 0.5 & b.d.1. & 0.05 \\
\hline & 2 & 0.5 & 82.9 & 18.9 & b.d.1. & b.d.1. & b.d.l. & 0.04 \\
\hline & 3 & 8.8 & 213.4 & 11.6 & b.d.1. & b.d.1. & b.d.1. & 0.05 \\
\hline & 4 & 2.4 & 106.9 & 8.9 & b.d.1. & b.d.1. & b.d.1. & 0.04 \\
\hline & 5 & b.d.l. & 62.0 & 8.1 & b.d.1. & b.d.1. & b.d.1. & 0.04 \\
\hline \multirow{5}{*}{ Dicranum scoparium } & 1 & 4.7 & 478.3 & 34.9 & 4.7 & 0.6 & b.d.1. & 0.07 \\
\hline & 2 & 8.6 & 217.1 & 21.9 & b.d.1. & b.d.1. & 1.20 & 0.06 \\
\hline & 3 & 11.0 & 338.6 & 37.0 & 4.8 & b.d.l. & b.d.1. & 0.06 \\
\hline & 4 & 4.8 & 191.9 & 35.9 & 5.8 & b.d.1. & b.d.1. & 0.08 \\
\hline & 5 & b.d.1. & 164.9 & 11.3 & 0.9 & b.d.1. & b.d.1. & 0.06 \\
\hline
\end{tabular}

b.d.l. - below the detection limit 
Table 3. Average ${ }^{210} \mathrm{Po},{ }^{238} \mathrm{U}$, total uranium concentration and values of the activity ratio ${ }^{234} \mathrm{U} /{ }^{238} \mathrm{U}$ in mosses samples collected in spring 2009 from Sobieszewo Island

\begin{tabular}{|c|c|c|c|c|c|}
\hline \multirow[t]{2}{*}{ Mosses species } & Site & \multicolumn{2}{|c|}{ [Bq kg ${ }^{-1}$ d. wt.] } & \multicolumn{2}{|l|}{ [mg kg${ }^{-1}$ d. wt.] } \\
\hline & 1 & $218 \pm 14$ & $1.80 \pm 0.19$ & $0.15 \pm 0.04$ & $1.00 \pm 0.07$ \\
\hline \multirow{4}{*}{$\begin{array}{l}\text { Pleurozium } \\
\text { schreberi }\end{array}$} & 2 & $278 \pm 14$ & $1.67 \pm 0.14$ & $0.14 \pm 0.02$ & $0.98 \pm 0.07$ \\
\hline & 3 & $344 \pm 11$ & $1.84 \pm 0.23$ & $0.16 \pm 0.02$ & $0.97 \pm 0.06$ \\
\hline & 4 & $327 \pm 11$ & $1.80 \pm 0.18$ & $0.15 \pm 0.04$ & $1.00 \pm 0.07$ \\
\hline & 5 & $427 \pm 15$ & $2.97 \pm 0.19$ & $0.26 \pm 0.05$ & $0.97 \pm 0.03$ \\
\hline \multirow{5}{*}{ Dicranum scoparium } & 1 & $165 \pm 9$ & $1.73 \pm 0.14$ & $0.15 \pm 0.04$ & $1.00 \pm 0.05$ \\
\hline & 2 & $147 \pm 7$ & $1.36 \pm 0.13$ & $0.12 \pm 0.01$ & $1.00 \pm 0.05$ \\
\hline & 3 & $160 \pm 9$ & $1.90 \pm 0.14$ & $0.16 \pm 0.03$ & $0.99 \pm 0.07$ \\
\hline & 4 & $133 \pm 1$ & $1.97 \pm 0.13$ & $0.17 \pm 0.02$ & $0.98 \pm 0.04$ \\
\hline & 5 & $168 \pm 6$ & $3.32 \pm 0.11$ & $0.28 \pm 0.01$ & $0.97 \pm 0.03$ \\
\hline
\end{tabular}

